\title{
Pengaruh Kepuasan Kerja dan Komitmen Organisasi terhadap Kinerja Karyawan Badan Penyelenggara Jaminan Sosial (BPJS) Kesehatan Cabang Ambon
}

\author{
Pieter N. R. Rehatta ${ }^{1)}$ \\ Universitas Pattimura \\ Saleh Tutupoho ${ }^{2)}$ \\ Universitas Pattimura \\ rehattapeter@yahoo.co.id
}

\begin{abstract}
"The Effect of Job Satisfaction and Organizational Commitment on Employee Performance of the Ambon Branch of BPJS on health institutions". The purpose of this study was to determine the effect of job satisfaction and organizational commitment on the Ambon branch of BPJS on health institutions. The population in this study were employees of the Ambon branch of BPJS on health institutions. The sample in this study were 32 employees. Data collection was carried out using a questionnaire. The data analysis method used was SPSS version 16. The results of multiple regression analysis are $\mathrm{Y}=0.280 \mathrm{X} 1+0.392 \mathrm{X} 2$. The independent variable that most influences the dependent variable is the organizational commitment variable (0.392), and the last is the job satisfaction variable (0.280). The results of the $t$ test show that all the independent variables (job satisfaction and organizational commitment) have a significant positive effect on the dependent variable (employee performance) where all the independent variables obtain a $t$ value greater than the $t$ table with a sig level of less than 0.05 . And the coefficient of determination ( $\mathrm{R}$ Square) obtained is 0.323 , this means that $32.3 \%$ of employee performance can be explained by job satisfaction and organizational commitment variables, while the remaining $67.7 \%$ is influenced by other variables not examined in this study. The implication of the above conclusions is that in an effort to improve employee performance, the Ambon branch of BPJS on health institutions should increase job satisfaction for employees, namely the leadership must provide more support for employees and must mutually cooperate between employees so that their sense of job satisfaction increases and increases commitment to oneself and at the company.
\end{abstract}

Keywords : job satisfaction, organizational commitment, employee performance

\section{Pendahuluan}

Sumber daya manusia adalah aset terpenting bagi suatu organisasi. Hal ini mempertegas bahwa karyawan atau tenaga kerja merupakan bagian yang penting bagi organisasi. Dengan dukungan para karyawan maka suatu organisasi dapat menjadi lebih kuat, sehingga organisasi akan dapat memenangkan persaingan serta kontribusi mereka bagi pencapaian tujuan organisasi sangat dihargai oleh orang-orang tingkat atas atau pimpinan organisasi (Mas'ud, 2002). Pengelolaan karyawan yang baik serta pembinaan hubungan yang harmonis antara manajer dan karyawan merupakan salah satu kunci utama dalam mencapai tujuan organisasi. Pencapaian tujuan organisasi ini merupakan salah satu indikator keberhasilan organisasi dalam menjalankan usahanya. 
Manajemen sumberdaya manusia pada umumnya adalah untuk menciptakan hubungan kerja yang serasi diantara para karyawan dan penyatupaduan sumber daya manusia secara efektif atau tujuan efisiensi dan kerja sama sehingga diharapkan akan meningkatkan produktivitas kerja (Sunyoto, 2013). Hal ini tentunya menjadi tanggung jawab bersama di antara para manajer dan karyawan. Manajer bertanggung jawab untuk memperhatikan pola kinerja karyawannya dan karyawan bertanggung jawab untuk menjalankan segala tugas dan peranan yang telah diberikan. Semakin baik pola hubungan kerja tersebut maka akan semakin baik pula manajemen suatu organisasi.

Salah satu cara manajer untuk membangun kinerja karyawan yang baik adalah dengan memperhatikan aspek kepuasan kerja. Menurut (Sunyoto, 2013) kepuasan kerja didefinisikan sebagai cerminan perasaan seseorang terhadap pekerjaannya. Hal ini terlihat pada sikap positif karyawan dalam memandang pekerjaannya dan segala sesuatu yang dihadapi di lingkungan kerjanya. Manajer harus selalu memantau aspek kepuasan kerja karena hal ini sangat berpengaruh terhadap tingkat absensi karyawan, perputaran tenaga kerja/ turnover, penyimpangan di tempat kerja, produktivitas, kinerja karyawan, dan masalah-masalah penting lainnya. Kepuasan kerja yang tinggi sangat mempengaruhi kondisi kerja yang positif dan dinamis sehingga mampu memberikan keuntungan yang nyata, tidak hanya bagi perusahaan tetapi bagi karyawan itu sendiri. Kinerja karyawan otomatis akan meningkatkan kinerja perusahaan.

Kinerja karyawan selain dipengaruhi oleh kepuasan kerja juga dapat dipengaruhi oleh komitmen organisasi. Komitmen organisasi menurut Stephen P. Robbins dan Timothy A. Judge (2008) adalah tingkat sampai mana seorang karyawan memihak sebuah organisasi serta tujuan-tujuan dan keinginannya untuk mempertahankan keanggotaan dalam organisasi tersebut. Terdapat suatu hubungan positif antara komitmen organisasi dengan produktivitas kerja. Sama seperti kepuasan kerja, komitmen organisasi juga memiliki hubungan dengan tingkat absensi karyawan maupun perputaran karyawan/ turnover, dan kinerja karyawan. Tingkat komitmen organisasi yang dimiliki oleh masing-masing karyawan berbeda satu dengan yang lain. Karyawan yang memiliki komitmen tinggi cenderung memiliki catatan kehadiran yang lebih baik dan masa kerja yang lebih lama dibandingkan dengan karyawan yang berkomitmen rendah. Karyawan dengan komitmen organisasi yang tinggi juga tidak sekadar bergabung dengan perusahaan secara fisik melainkan juga bersedia untuk melakukan pekerjaan di luar tugas yang diberikan kepadanya.

Badan Penyelenggara Jaminan Sosial (BPJS) Kesehatan menyadari bahwa SDM merupakan modal dan kekuatan yang harus dimiliki demi keberlangsungan masa depan BPJS. Seperti dijelaskan oleh Sudarmanto (2009) SDM dianggap sebagai salah satu faktor sangat penting karena termasuk faktor yang menentukan keberhasilan atau kegagalan organisasi dalam mencapai tujuan, baik pada organisasi publik maupun private. Sehingga, sudah seharusnya SDM dikelola secara tepat salah satunya dengan menciptakan kepuasan kerja bagi karyawannya. Fenomena turunnya kinerja karyawan diakibatkan karena beberapa indikator dari kepuasaan kerja, karyawan yang cenderung kurang puas terhadap rekan kerja dan atasan cenderung mementingkan diri sendiri bahkan terkadang tidak marangkul karyawannya. Fenomena-fenomena ini adalah sedikit gambaran dari sisi tersendiri sebuah organisasi yang menjadikan kurangnya komitmen organisasi bagi karyawan. Data Kinerja karyawan yang tersaji berikut, adalah wujud fenomena pada BPJS Kesehatan Cabang Ambon. 
Pieter N.R. Rehatta, Saleh Tutupoho

Tabel 1.

Data Kinerja Karyawan BPJS Kesehatan Cabang Ambon

Tahun 2016 s/d 2018

\begin{tabular}{|c|c|c|c|c|c|c|}
\hline \multirow{2}{*}{$\begin{array}{c}\text { Kinerja } \\
\text { Karyawan }\end{array}$} & \multicolumn{2}{|c|}{$\mathbf{2 0 1 6}$} & \multicolumn{2}{c|}{2017} & \multicolumn{2}{c|}{2018} \\
\cline { 2 - 7 } & Nilai & Keterangan & Nilai & $\begin{array}{c}\text { Keteranga } \\
\text { n }\end{array}$ & Nilai & Keterangan \\
\hline Kualitas Kerja & 95 & Sangat Baik & 95 & Sangat Baik & 85 & Baik \\
\hline Kuantitas Kerja & 95 & Sangat Baik & 93 & Sangat Baik & 80 & Baik \\
\hline $\begin{array}{c}\text { Tanggung } \\
\text { Jawab }\end{array}$ & 93 & Sangat Baik & 90 & Baik & 75 & Cukup \\
\hline $\begin{array}{c}\text { Pelaksanaan } \\
\text { Tugas }\end{array}$ & 90 & Baik & 90 & Baik & 73 & Cukup \\
\hline Jumlah & 373 & & 368 & & 313 & \\
\hline Rata-rata & $\begin{array}{c}93,25 \\
\%\end{array}$ & Sangat Baik & $92 \%$ & Sangat Baik & $78,25 \%$ & Cukup \\
\hline
\end{tabular}

Sumber : BPJS Cabang Ambon

Dari tabel 1, terlihat kondisi kinerja karyawan BPJS Kesehatan Cabang Ambon sangat baik di tahun 2016, namun mengalami penurunan pada tahun-tahun berikutnya, bahkan pada tahun 2018 mengalami penurun sebesar 13,75 \% dan berada pada kategori cukup. Sehingga diindikasikan bahwa terjadi masalah pada kinerja karyawan BPJS Kesehatan Cabang Ambon.

\section{Landasan Teori dan Pengembangan Hipotesis}

\section{Landasan Teori}

\section{Kinerja Karyawan}

Menurut Marihot Tua Efendi Hariandja (2002) kinerja merupakan hasil kerja yang dihasilkan oleh pegawai atau perilaku nyata yang ditampilkan sesuai dengan perannya dalam organisasi. Sedangkan Juliansyah Noor (2013) mengartikan kinerja sebagai suatu kondisi yang harus diketahui dan dikonfirmasikan kepada pihak tertentu untuk mengetahui tingkat pencapaian hasil individu dihubungkan dengan visi yang diemban suatu organisasi, serta mengetahui dampak positif dan negatif dari suatu kebijakan operasional. Robert L. Mathis dan John H. Jackson (2002) memaparkan bahwa kinerja pada dasarnya adalah apa yang dilakukan atau tidak dilakukan karyawan. Kinerja merupakan suatu hal yang penting dalam usaha organisasi untuk mencapai tujuannya, sehingga berbagai kegiatan harus dilakukan organisasi untuk meningkatkannya. Salah satu cara yang ditempuh adalah melalui penilaian kinerja.

Ricky Griffin (2002) mendefinisikan penilaian kinerja sebagai suatu penilaian formal mengenai seberapa baik karyawan melakukan pekerjaan mereka. Dimana aspek-aspek kinerja karyawan dapat dilihat sebagai berikut: a) hasil kerja, bagaimana seseorang itu mendapatkan sesuatu yang dikerjakannya. b) kedisiplinan yaitu ketepatan dalam menjalankan tugas, bagaimana seseorang menyelesaikan pekerjaannya sesuai dengan tuntutan waktu yang dibutuhkan. c) tanggung jawab dan kerja sama, bagaimana seseorang bisa bekerja dengan baik dalam pengawasan maupun tidak. Tujuan utama penilaian kinerja adalah untuk memotivasi karyawan dalam mencapai sasaran strategik organisasi dan dalam mematuhi standar perilaku yang ditetapkan sebelumnya (Mulyadi 2007). Kinerja seseorang di pengaruhi oleh banyak 
faktor yang dapat di golongkan pada 3 (tiga) kelompok yaitu kompensasi individu orang yang bersangkutan, dukungan organisasi, dan dukungan manejemen. (Simanjuntak 2011: 11)

\section{Kepuasan Kerja}

Menurut Sondang P. Siagian (2003) kepuasan kerja adalah suatu cara pandang seseorang, baik yang bersifat positif maupun bersifat negatif mengenai pekerjaannya. Hal ini mencerminkan bahwa kepuasan kerja seseorang tergantung bagaimana penilaian individu tersebut terhadap pekerjaannya, apakah dapat membuat dirinya puas atau tidak. Selanjutnya Hessel Nogi S. Tangkilisan (2007) menyatakan bahwa kepuasan kerja merupakan tingkat kesenangan yang dirasakan seseorang atas peranan atau pekerjaannya dalam suatu organisasi. Berdasarkan beberapa pendapat tersebut dapat ditarik kesimpulan bahwa kepuasan kerja adalah perasaan yang muncul setelah karyawan melakukan penilaian terhadap organisasi dan terhadap dirinya sendiri melalui tanggung jawab yang dibebankan kepadanya dengan harapan mendapatkan imbalan diantaranya adalah penghargaan. Robert Hoppock dalam (Hoy, 2001:303) memberikan definisi kepuasan kerja sebagai kombinasi kondisi psikologis, fisiologis dan lingkungan yang menyebabkan orang berkata saya puas dengan pekerjaan saya. Maksudnya, kepuasan kerja adalah kondisi dimana individu menyukai pekerjaannya. Dengan demikian kepuasan kerja mencerminkan perasaan seseorang terhadap pekerjaan yaitu cara pandang pegawai terhadap pekerjaan mereka.

Fred Luthans (2006) memaparkan enam karakteristik yang memengaruhi kepuasan kerja yaitu: 1. Pekerjaan Itu Sendiri, 2. Gaji, 3. Promosi, 4. Pengawasan, 5. Kelompok Kerja, dan 6. Kondisi Kerja. Dalam mempertimbangkan sejumlah aspek-aspek pekerjaan yang mempengaruhi kepuasan kerja, karyawan akan memandang sejumlah aspek yang dianggap penting dan mengabaikan aspek lain yang jarang dipertimbangkan. Sutrisno (2011:80) menyimpulkan faktor-faktor yang dapat mempengaruhi kepuasan kerja, yaitu: 1. Faktor psikologis, 2. Faktor sosial, 3. Faktor fisik, dan 4. Faktor finansial.

Robbins dan Judge (2008:108) mengatakan bahwa ada konsekuensi ketika karyawan menyukai pekerjaan mereka dan ada konsekuensi ketika karyawan tidak menyukai pekerjaan mereka. Sebuah kerangka teoritis (kerangka keluar, aspirasi, kesetiaan dan pengabaian) sangat bermanfaat dalam memahami konsekuensi dari ketidakpuasan. Respon-respon tersebut didefinisikan sebagai berikut: 1. Keluar (Exit), 2. Suara (Voice), 3. Kesetiaan (Loyality), serta 4. Pengabaian (Neglect)

\section{Komitmen Organisasi}

Menurut John M. Ivancevich (2006) komitmen organisasi adalah perasaan identifikasi, keterlibatan, dan kesetiaan yang diekspresikan oleh karyawan terhadap perusahaan. Fred Luthans (2006) mengartikan komitmen organisasi sebagai suatu sikap yang merefleksikan loyalitas karyawan pada organisasi dan proses berkelanjutan di mana anggota organisasi mengekspresikan perhatiannya terhadap organisasi dan keberhasilan serta kemajuan yang bekerlanjutan. Jika para karyawan berkomitmen pada organisasi, mereka mungkin akan lebih produktif. Komitmen organisasi merupakan tingkat kepercayaan dan penerimaan tenaga kerja terhadap tujuan organisasi dan mempunyai keinginan untuk tetap ada di dalam organisasi tersebut (Robert L. Mathis dan John H. Jackson, 2001).

Komitmen organisasi bersifat multidimensi, oleh karena itu terdapat perkembangan dukungan untuk tiga model komponen. Tiga model komponen komitmen organisasi menurut Meyer dan Allen (dalam Fred Luthans, 2006) adalah: 1. Komitmen Afektif, 2. Komitmen Kelanjutan, dan 3. Komitmen Normatif. Menurut David (1997 dalam Sopiah, 2008:163) mengemukakan empat faktor yang mempengaruhi komitmen karyawan pada organisasi yaitu: 
1. Faktor personal, misalnya usia, jenis kelamin, tingkat pendidikan, pengalaman kerja, kepribadian, dll.

2. Karakteristik pekerjaan, misalnya besar/kecilnya organisasi, bentuk organisasi (sentralisasi/desentralisasi), kehadiran serikat pekerja.

3. Pengalaman kerja, pengalaman kerja karyawan sangat berpengaruh terhadap tingkat komitmen karyawan pada organisasi.

\section{Pengembangan Hipotesis}

Hipotesis atau hipotesa adalah jawaban sementara terhadap masalah yang masih bersifat praduga karena masih harus dibuktikan kebenarannya. Hipotesis menjadi teruji apabila semua gejala yang timbul tidak bertentangan dengan hipotesis tersebut. Dalam upaya pembuktian hipotesis, peneliti dapat saja dengan sengaja menimbulkan atau menciptakan suatu gejala. Kesengajaan ini disebut percobaan atau eksperimen.

\section{Pengaruh Kepuasaan Kerja terhadap Kinerja Karyawan}

Kepuasan kerja merupakan salah satu faktor yang sangat penting untuk mendapatkan hasil yang optimal ketika seorang merasakan kepuasan dalam bekerja tentunya ia akan berupaya semaksimal mungkin dengan segenap kemampuan yang dimilikinya untuk menghasilkan tugas pekerjaannya. Kinerja karyawan adalah salah satu hal yang penting dalam setiap organisasi, karena kinerja merupakan hasil kerja yang dilakukan setiap pegawai untuk memperoleh hasil yang optimal. Dengan kinerja yang tinggi maka tujuan organisasi akan mudah tercapai.

Penelitian yang dilakukan oleh Diana Sulianti (2009) mengatakan bahwa kinerja seseorang akan meningkat ketika kepuasan kerja dari karyawan berada pada posisi yang tinggi. Hal ini dibuktikan bahwa kepuasan kerja berpengaruh positif terhadap kinerja karyawan sebesar 0,715 yang berarti setiap ada kenaikan Kepuasan Kerja maka akan menaikkan Kinerja Karyawan sebesar 0,715 .

Penelitian yang dilakukan Mega Arum (2012) menunjukkan kepuasan kerja berpengaruh positif terhadap kinerja karyawan dengan koefisien korelasi sebesar 0,416. Berdasarkan penelitian - penelitian terdahulu dapat dirumuskan hipotesis : (H1) : kepuasan kerja berpengaruh positif terhadap kinerja karyawan.

\section{Pengaruh Komitmen Organisasi Terhadap Kinerja Karyawan}

Penelitian yang dilakukan oleh Suwardi dan Joko utumo (2011) menunjukkan bahwa komitmen organisasi berpengaruh positif terhadap kinerja karyawan dengan koefisien korelasi sebesar 0,393 .

Penelitian yang dilakukan Yenni Verawati (2011) menunjukkan bahwa komitmen organisasi berpengaruh positif dengan kinerja karyawan dengan koefisien regresi sebesar 0,289 .

Berdasarkan penelitian terdahulu dapat dirumuskan hipotesis :

(H2) : Komitmen organisasi berpengaruh positif terhadap kinerja karyawan. 


\section{Kerangka Pemikiran}

Berdasarkan penerapan landasan teori dan hipotesis, maka kerangka pemikiran yang dihasilkan seperti berikut :

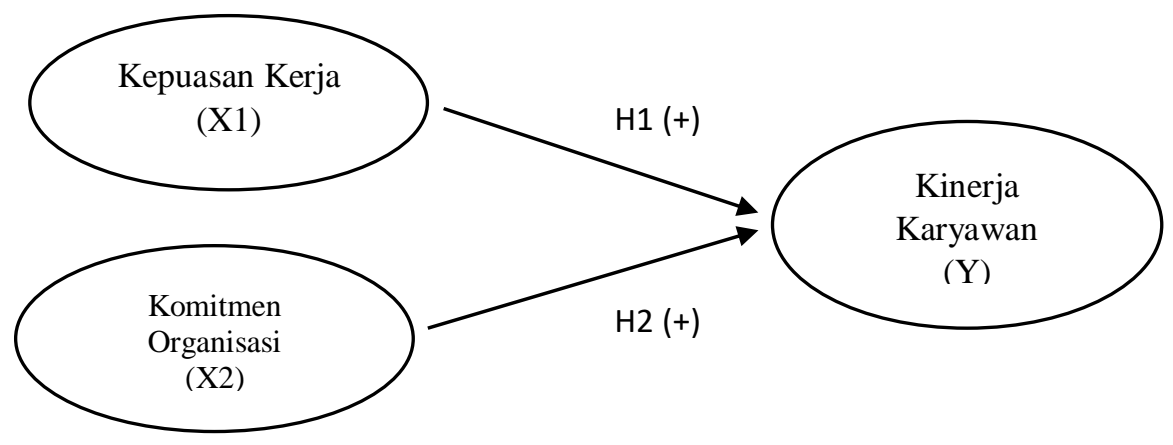

Gambar 1. Kerangka Pemikiran

\section{Metode Penelitian}

Penelitian ini menggunakan uji kausalitas (pengaruh) yang berarti menguji hubungan yang bersifat sebab akibat. Jadi terdapat variabel independen (variabel yang mempengaruhi) dan dependen (dipengaruhi), yang mana objek dalam penelitian ini adalah karyawan BPJS Kesehatan Cabang Ambon. Penelitian ini dilakukan dengan menggunakan teknik analisa regresi dengan metode sensus terhadap 32 orang karyawan BPJS Kesehatan Cabang Ambon. Metode Sensus menurut Sugiono (2007 : 61), yaitu teknik penentuan sampel yang menggunakan seluruh anggota populasi sebagai sampel. Metode pengumpulan data dengan memberikan kuisioner terhadap 32 subyek penelitian dengan menggunakan instrumen yang sebelumnya di uji cobakan terlebih dahulu kepada subyek penelitian yang berbeda dengan mengambil aspek-aspek dari Kepuasan Kerja, Komitmen Organisasi dan Kinerja Karyawan dari teori Luthans, Robbins serta Mangkunagara.

\section{Defenisi Operasional Variabel}

Kepuasan Kerja (Luthans, 2006:243) adalah keadaan emosi yang senang atau emosi positif yang berasal dari penilaian pekerjaan atau pengalaman kerja seseorang.

Robbins dan Judge (2007), mendefinisikan Komitmen Organisasi sebagai suatu keadaan dimana seorang individu memihak organisasi serta tujuan-tujuan dan keinginannya untuk mempertahankan keanggotaannya dalam organisasi.

Kinerja adalah hasil kerja baik secara kualitas maupun kuantitas yang dicapai oleh seseorang dalam melaksanakan tugas sesuai tanggung jawab yang diberikan (Mangkunagara, 2002:22).

\section{Hasil dan Pembahasan}

\section{Uji Validitas}

Uji validitas dapat dilakukan dengan melakukan korelasi bivariate antara masing-masing skor indikator dengan total skor konstruk (Ghozali, 2009:50). Hasil pengujian dengan menggunaan program SPSS 16 menunjukkan nilai Coeficient correlation pearson pada masingmasing variabel dapat dilihat pada tabel 2. Uji Validitas. 
Tabel 2. Uji Validitas

\begin{tabular}{|c|c|c|c|c|c|}
\hline No & Variabel & Indikator & r hitung & $\mathrm{r}$ tabel & Keterangan \\
\hline 1 & $\begin{array}{c}\text { Kepuasan } \\
\text { Kerja }\end{array}$ & $\begin{array}{ll}\text { - } & \text { Indikator } 1 \\
\text { - } & \text { Indikator } 2 \\
\text { - } & \text { Indikator } 3 \\
\text { - } & \text { Indikator } 4 \\
\text { - } & \text { Indikator } 5\end{array}$ & $\begin{array}{l}0,588 \\
0,604 \\
0,490 \\
0,595 \\
0,704\end{array}$ & $\begin{array}{l}0,349 \\
0,349 \\
0,349 \\
0,349 \\
0,349\end{array}$ & $\begin{array}{l}\text { Valid } \\
\text { Valid } \\
\text { Valid } \\
\text { Valid } \\
\text { Valid }\end{array}$ \\
\hline 2 & $\begin{array}{l}\text { Komitmen } \\
\text { Organisasi }\end{array}$ & $\begin{array}{ll}\text { - } & \text { Indikator } 1 \\
\text { - } & \text { Indikator } 2 \\
\text { - } & \text { Indikator } 3 \\
\end{array}$ & $\begin{array}{l}0,590 \\
0,700 \\
0,583\end{array}$ & $\begin{array}{l}0,349 \\
0,349 \\
0,349 \\
\end{array}$ & $\begin{array}{l}\text { Valid } \\
\text { Valid } \\
\text { Valid }\end{array}$ \\
\hline 3 & $\begin{array}{c}\text { Kinerja } \\
\text { Karyawan }\end{array}$ & $\begin{array}{ll}\text { - } & \text { Indikator } 1 \\
\text { - } & \text { Indikator } 2 \\
\text { - } & \text { Indikator } 3 \\
\text { - } & \text { Indikator } 4\end{array}$ & $\begin{array}{l}0,350 \\
0,471 \\
0,640 \\
0,344\end{array}$ & $\begin{array}{l}0,349 \\
0,349 \\
0,349 \\
0,349\end{array}$ & $\begin{array}{l}\text { Valid } \\
\text { Valid } \\
\text { Valid } \\
\text { Valid }\end{array}$ \\
\hline
\end{tabular}

Sumber: Data Primer diolah 2019

Dari tabel menunjukan nilai koefisien Product Moment (r) lebih besar dari 0.5 serta nilai sig 0.000. nilai koefisen Product Moment (r) indikator lebih besar dari 0.5, hal tersebut berarti keseluruhan indikator valid untuk pengujian selanjutnya.

\section{Uji Reliabilitas}

Pengukuran reliabilitas dilakukan dengan cara one shot atau pengukuran sekali saja dengan alat bantu SPSS uji statistik Cronbach Alpha $(\alpha)$. Suatu variabel diatakan reliabel jika memberikan nilai Cronbach's Alpha > 0,60 (Sugiono, 2014).

Hasil pengujian dengan menggunakan program SPSS 16 menunjukan nilai cronbach alpha variabel yang diteliti disajikan dalam tabel berikut ini :

Tabel 3. Uji Reliabilitas Variabel

\begin{tabular}{|l|c|c|}
\hline \multicolumn{1}{|c|}{ Variabel } & Alpha & Keterangan \\
\hline Kepuasan Kerja (X1) & 0,732 & Reliabel \\
\hline Komitmen Organisasi (X2) & 0,717 & Reliabel \\
\hline Kinerja Karyawan (Y) & 0,708 & Reliabel \\
\hline
\end{tabular}

Sumber : Data Primer diolah 2019

Berdasarkan tabel 3 dapat diketahui bahwa semua hasil uji reliabilitas menunjukan bahwa variable kepuasan kerja, komitmen organisasimemiliki nilai Cronbach's Alpha lebih besar dri 0,60. Dengan demikian dapat disimpulkan bahwa data kuisioner yang digunakan dalam penelitian ini sudah reliabel atau sudah dapat diterima.

\section{Uji Asumsi Klasik \\ Uji Normalitas}

Pengujian normal dilakukan terhadap residual regresi. Pengujian dilakukan dengan menggunakan grafikP-PPlot. Data yang normal adalah data yang membentuk titik-titik yang menyebar tidak jauh dari garis diagonal, seperti gambar 2 dibawah ini : 


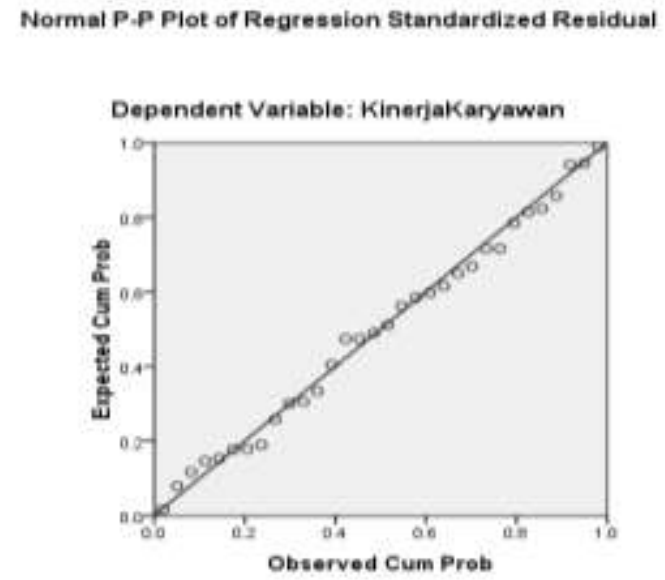

Gambar 2. Normal P-P Plot

Dapat disimpulkan bahwa pad garis normal probability plot terlihat di titik-titik menyebar disekitar garis diagonal dan penyebarannya mengikuti arah garis diagonal, maka garis di atas menunjukan bahwa model regresi layak di pakai karena memenuhi asumsi normalitas.

\section{Uji Multikolonieritas}

Uji multikolinieritas bertujuan untuk menguji apakah pada model regresi ditemukan adanya korelasi antar variabel bebas (independen). Model regresi yang baik seharusnya tidak terjadi korelasi diantara variabel bebasnya. Dengan menggunakan nilai tolerance, nilai yang berbentuk harus di atas 10\% dengan menggunakan VIF (Variance Inflation Factor), nilai yang berbentuk harus kurang dari 10, bila tidak maka akan terjadi multikolinieritas dan model regresi tidak layak untuk digunakan (Imam Ghozali 2005:11). Hasil uji multikolinearitas tersaji pada tabel 4 :

Tabel 4. Uji Multikolonieritas

\begin{tabular}{|c|c|c|c|}
\hline Variabel & $\begin{array}{c}\text { Nilai } \\
\text { VIF }\end{array}$ & $\begin{array}{c}\text { Nilai } \\
\text { Tolerance }\end{array}$ & Keterangan \\
\hline $\begin{array}{c}\text { Kepuasan Kerja } \\
\text { (X1) }\end{array}$ & 1.003 & 0.997 & $\begin{array}{c}\text { Tidak ada indikasi kolinearitas } \\
\text { antar variabel bebas }\end{array}$ \\
\hline $\begin{array}{c}\text { Komitmen Organisasi } \\
(\mathrm{X} 2)\end{array}$ & 1.003 & 0.997 & $\begin{array}{c}\text { Tidak ada indikasi kolinearitas } \\
\text { antar variabel bebas }\end{array}$ \\
\hline
\end{tabular}

Sumber: Data primer diolah 2019

Hasil nilai tolerance tiap variabel sebesar 0,997, Variabel X1 dan nilai tolerance untuk variabel X2 0,997, mengandung makna bahwa tidak ada variabel indenpenden/bebas yang memiliki nilai tolerance kurang dari 0.10 yang berarti tidak ada kolerasi antar variabel indenpenden yang nilainya lebih dari $90 \%$. Hasil perhitungan nilai Variance Inflation Factor (VIF) juga menunjukan bahwa VIF > 10, hal tersebut berarti dan dapat disimpulkan bahwa tidak ada multikolinieritas antar variabel indenpenden dalam model regresi. 


\section{Uji Heterokedastis}

Pengujian heterokedisitas dilakukan dengan menggunakan Scatterplot. Jika tidak terdapat variabel yang signifikan maka dapat disimpulkan tidak adanya masalah heteroskedastisitas. Berikut adalah hasil uji heteroskedastisitas yang berupa grafik scatterplots

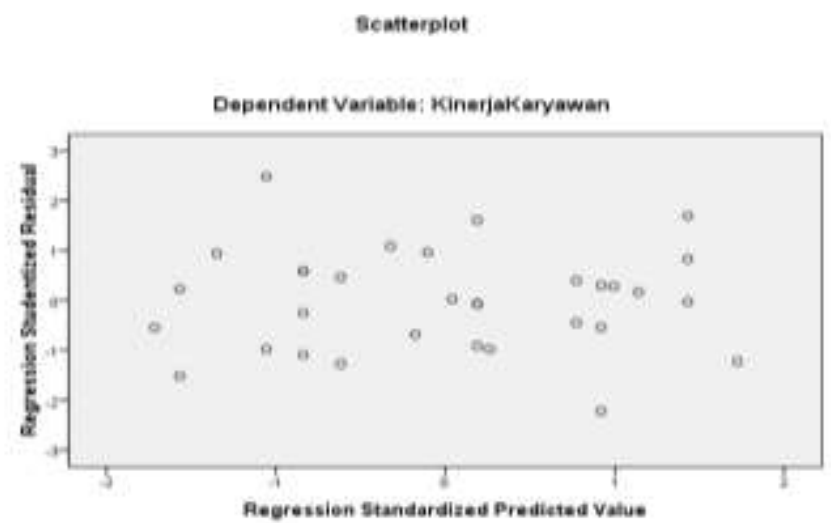

Gambar 3. Grafik Scatterplots

Hasil pengujian heteroskedastisitas menunjukkan tidak terdapat pola yang jelas dari titik-titik tersebut. Hal ini menunjukkan bahwa model regresi tidak memiliki gejala adanya heteroskedastisitas, yang berarti bahwa tidak ada gangguan yang berarti dalam model regresi ini.

\section{Uji Hipotesis}

\section{Uji Signifikan Persial (Uji t)}

Uji t digunakan untuk mengetahui pengaruh secara parsial variabel independen (kepuasan kerja dan komitmen organisasi) terhadap variabel dependen (kinerja karyawan). Berikut akan di jelaskan pengujian masing-masing variable secara parsial.

Tabel 5. Hasil Uji t Coefficients ${ }^{\mathrm{a}}$

\begin{tabular}{|c|c|c|c|c|c|c|}
\hline \multirow{2}{*}{\multicolumn{2}{|c|}{ Model }} & \multicolumn{2}{|c|}{$\begin{array}{c}\text { Unstandardized } \\
\text { Coefficients } \\
\end{array}$} & \multirow{2}{*}{$\begin{array}{c}\begin{array}{c}\text { Standardized } \\
\text { Coefficients }\end{array} \\
\text { Beta }\end{array}$} & \multirow[b]{2}{*}{$\mathrm{t}$} & \multirow[b]{2}{*}{ Sig. } \\
\hline & & B & Std. Error & & & \\
\hline \multirow[t]{3}{*}{1} & (Constant) & 5.730 & 2.741 & & 2.090 & .045 \\
\hline & Kepuasan Kerja & .280 & .123 & .356 & 2.279 & .030 \\
\hline & $\begin{array}{l}\text { Komitmen } \\
\text { Organisasi }\end{array}$ & .392 & .158 & .389 & 2.489 & .019 \\
\hline
\end{tabular}

Sumber : Data primer diolah 2019

\section{a. Dependent Variable: Kinerja}

Karyawan 


\section{Hasil Uji Hipotesis Pertama}

Dari tabel 5 hasil pengujian menunjukan bahwa variabel kepuasan kerja memperoleh nilai signifikansi sebesar 0.30 , nilai ini lebih kecil dari $\alpha=5 \%(0.000<0.05)$. Koefisien transformasi regresi X1 atau untuk variabel kepuasan kerja adalah sebesar 0.280. Nilai koefisien yang negatif secara parsial berpengaruh signifikan terhadap kinerja karyawan. Maka dalam hal ini, untuk hipotesis pertama dapat diterima.

\section{Hasil Uji Hipotesis Kedua}

Dari tabel 5 hasil pengujian menunjukan bahwa variabel komitmen organisasi memperoleh nilai signifikansi sebesar 0.19 , nilai ini lebih kecil dari $\alpha=5 \%(0.000<0.05)$. Koefisien transformasi regresi X2 atau untuk variabel komitmen organisasi adalah sebesar 0.392. Nilai koefisien yang positif secara parsial berpengaruh signifikan terhadap kinerja karyawan. Maka dalam hal ini, untuk hipotesis kedua dapat diterima.

\section{Analisis Regresi Linier Berganda}

Analisis regresi linier berganda digunakan untuk mengetahui besarnya pengaruh variabel kepuasan kerja dan komitmen organisasisecara parsial maupun secara bersama-sama terhadap kinerja karyawan BPJS Cabang Ambon. Perhitungan statistik dalam analisis regresi linier berganda dijelaskan pada Tabel 6 berikut ini :

Tabel 6. Analisis Regresi Linier Berganda Coefficients ${ }^{\mathrm{a}}$

\begin{tabular}{|c|c|c|c|c|c|c|c|c|}
\hline \multirow{2}{*}{\multicolumn{2}{|c|}{ Model }} & \multicolumn{2}{|c|}{$\begin{array}{l}\text { Unstandardized } \\
\text { Coefficients }\end{array}$} & \multirow{2}{*}{$\begin{array}{c}\text { Standardized } \\
\text { Coefficients } \\
\text { Beta }\end{array}$} & \multirow[b]{2}{*}{$\mathrm{T}$} & \multirow[b]{2}{*}{ Sig. } & \multicolumn{2}{|c|}{$\begin{array}{l}\text { Collinearity } \\
\text { Statistics }\end{array}$} \\
\hline & & $\mathrm{B}$ & $\begin{array}{l}\text { Std. } \\
\text { Error }\end{array}$ & & & & $\begin{array}{c}\text { Toleranc } \\
\mathrm{e}\end{array}$ & VIF \\
\hline \multirow[t]{3}{*}{1} & (Constant) & 5.730 & 2.741 & & 2.090 & .045 & & \\
\hline & KepuasanKerja & .280 & .123 & .356 & 2.279 & .030 & .997 & 1.003 \\
\hline & $\begin{array}{l}\text { KomitmenOrgani } \\
\text { sasi }\end{array}$ & .392 & .158 & .389 & 2.489 & .019 & .997 & 1.003 \\
\hline
\end{tabular}

a. Dependent Variable: Kinerja

Karyawan

Sumber : Data primer SPSS 16 diolah, 2019

Berdasarkan tabel 6 diatas, dengan rumus regresi berganda :

$\mathrm{Y}=5.730+0,280 \mathrm{X} 1+0.392 \mathrm{X} 2+\mathrm{e}$

Dimana :

Interpretasi dari regresi di atas dimaksudkan :

1. Konstanta (a)

Konstanta sebesar 5.730 menunjukan konstanta dari Kinerja Karyawan (Y)

2. Kepuasan Kerja (X1)

Koefisien regresi kepuasan kerja (X1) sebesar 0.280. Adanya hubungan yang positif ini, berarti bahwa antara kepuasan kerja dengan kinerja karyawan menunjukan hubungan yang searah, artinya apabilah karyawan merasa puasa dalam menjalankan tugas akan meningkatkan kinerja karyawan. 


\section{Komitmen Organisasi (X2)}

Koefisien regresi komitmen organisasi (X2) sebesar 0.392. Adannya hubungan yang positif ini, berarti bahwa antara komitmen organisasi dengan kinerja karyawan menunjukan hubungan yang searah, artinya apabilah karyawan berkomitmen dalam sebuah organisasi atau perusahaan itu maka akan berdampak pada peningkatan kinerja karyawan itu sendiri.

4. $\mathrm{e}=$ Faktor Galat

\section{Analisis Koefisien Determinasi $\left(\mathbf{R}^{2}\right)$}

Analisis koefisien determinasi digunakan untuk mengetahui persentase sumbangan pengaruh variabel indpenden secara bersama-sama terhadap variabel dependen (Priyatno, 2016). Adapun hasil uji determinasi dalam penelitian ini adalah sebagai berikut:

Tabel 7. Koefisien Determinasi Model Summary ${ }^{\mathrm{b}}$

\begin{tabular}{|c|r|r|r|r|r|}
\hline Model & R & R Square & $\begin{array}{c}\text { Adjusted R } \\
\text { Square }\end{array}$ & $\begin{array}{c}\text { Std. Error of } \\
\text { the Estimate }\end{array}$ & Durbin-Watson \\
\hline 1 & $.568^{\mathrm{a}}$ & .323 & .276 & 1.191 & 1.511 \\
\hline
\end{tabular}

Sumber: Data Primer diolah 2019

Dari hasil perhitungan dengan menggunakan program SPSS versi 16 dapat diketahui bahwa koefisien determinasi (R Square ) yang diperoleh sebesar 0.323. Hal ini berarti 32,3\% kinerja karyawan dapat dijelaskan oleh variabel kepuasan kerja dan komitmen organisasi, sedangkan sisanya yaitu 67,7\% kinerja karyawan dipengaruhi oleh variabel-variabel lainnya yang tidak dimasutkan dalam model ini, yang berarti $\mathrm{H} 0$ diterima atau dapat dikatakan model pada regresi ini normal.

\section{Hipotesis}

\section{Pengaruh Kepuasan Kerja Terhadap Kinerja Karyawan}

Pada penelitian ini, variabel Kepuasan Kerja memiliki pengaruh yang signifikan terhadap kinerja karyawan dengan nilai koefisien 0,280 dengan demikian hipotesis pada kepuasan kerja diterima. Secara deskriptif tanggapan responden terhadap variabel kepuasan kerja dengan nilai rata-rata karyawan menyatakan baik, hal ini tunjukkan dengan nilai mean 3,75 .

Penelitian ini bertujuan untuk mengetahui apakah yang menyebabkan karyawan tidak puas kerja yang akhirnya mengganggu kinerja karyawan pada perusahaan. Dari hasil pembahasan menunjukkan bahwa berupa rasa senang atau tidak senang, situasi kerja, interkasi dengan orang lain, dan perasaan nyaman akan pekerjaannya itu. Sehingga faktor tersebut memberikan rasa puas kepada individu, dan menjadikan individu itu bekerja lebih keras dan mampu meningkatkan kinerja karyawan dengan nilai koefisien 0,231 lebih kecil dengan demikian variabel kepuasan kerja memiliki pengaruh terhadap kinerja karyawan. Sedangkan yang dihadapi oleh peneliti, faktor kepuasan kerja sangat mempengaruhi kinerja karyawan dengan nilai koefisien 0,280 .

Pada pengujian hipotesis, variabel kepuasan kerja memiliki pengaruh terhadap kinerja karyawan disebabkan karena dilihat dengan nilai koefisien sebesar 0,280 maka kepuasan kerja mempunyai pengaruh signifikan terhadap kinerja karyawan. 


\section{Pengaruh Komitmen Organisasi Terhadap Kinerja Karyawan}

Pada penelitian ini, variabel Komitmen Organisasi memiliki pengaruh yang signifikan terhadap kinerja karyawan dengan nilai koefisien 0,392 dengan demikian hipotesis pada kepuasan kerja diterima. Secara deskriptif tanggapan responden terhadapvariabel komitmen organisasi dengan nilai rata-rata karyawan menyatakan baik, hal ini tunjukkan dengan nilai mean 3,36. Penelitian ini juga mendukung teori yang dikemukakan Stephen P. Robbins dan Timothy A. Judge (2008) dimana komitmen organisasi adalah tingkat sampai mana seorang karyawan memihak sebuah organisasi serta tujuan-tujuan dan keinginannya untuk mempertahankan keanggotaan dalam organisasi tersebut.

Dalam penelitian ini, faktor komitmen organisasi sangat mempengaruhi kinerja karyawan dengan nilai koefisien 0,392 lebih besar dari kepuasan kerja dengan demikian kepuasan kerja dan komitmen organisasi memiliki pengaruh terhadap kinerja karyawan.

\section{Kesimpulan}

Penelitian ini bertujuan untuk mengetahui pengaruh variabel kepuasan kerja dan komitmen organisasi terhadap kinerja karyawan BPJS Kesehatan Cabang Ambon. Dan untuk mengetahui pengaruh terbesar dari kedua variable independen tersebut. Responden dalam penelitian ini berjumlah 32 orang responden, dari rumusan masalah penelitian yang diajukan, maka analisis data yang telah dilakukan dan pembahasan yang telah dikemukakan pada bab sebelumnya, dapat ditarik beberapa kesimpulan dari penelitian ini adalah sebagai berikut :

1. Kepuasan kerja dengan indikator kepuasan terhadap rekan kerja, kepuasan terhadap pendapatan, kepuasan terhadap atasan, kepuasan terhadap pekerjaan itu sendiri dan kepuasan kerja terhadap peluang promosi berpengaruh signifikan terhadap kinerja karyawan maka hipotesis diterima. Dan dari hasil olahan data regresi maka dapat disimpulkan bahwa kepuasan kerja mempunyai hubungan positif dan signifikan terhadap kinerja karyawan pada BPJS Kesehatan Cabang Ambon, dimana semakin tinggi tingkat kepuasan kerja dari karyawan, maka kinerja karyawan akan semakin meningkat.

2. Komitmen organisasi dengan indikator komitmen afektif, komitmen kelanjutan dan komitmen normatif, berpengaruh pada kinerja karyawan BPJS Kesehatan Cabang Ambon, maka hipotesis diterima.

\section{Daftar Pustaka}

Edy, Sutrisno. 2011. Manajemen Sumber Daya Manusia. Penerbit: Jakarta, Kencana. Fred Luthans. 2006. Perilaku Organisasi. Edisi Sepuluh, PT. Andi: Yogyakarta.

Ghozali, Imam, 2009. Aplikasi Analisis Multivariate dengan Program SPSS. Semarang: Badan Penerbit UNDIP.

Ghozali, Imam. 2005. Aplikasi Analisis Multivariate dengan SPSS. Semarang: Badan Penerbit UNDIP.

Griffin, W, Ricky dan Ronald J Ebert. 2002. Management, Erlangga, Jakarta.

Hoppock, R. 935. Job Satisfaction. New York: Harper and Brothers.

Hoy, W.K. \& Miskel, C.G. 2008. Educational administration: Theory, research and practice, 8thedition. Boston: McGraw-Hill.

Ivancevich M. John. 2006. Perilaku dan Manajemen Organisasi, Edisi Ke-7, Penerbit Erlangga Luthans, Fred. 2006. Perilaku Organisasi. Yogyakarta. ANDI.

Mangkunagara. 2002. Manajemen Sumber Daya Manusia. Bandung : Rosda

Mas'ud Fuad. 2002. Sumber Daya Manusia, Edisi Keempat, Penerbit Erlanggan, Jakarta. Edisi

Pertama, CV. Cahaya. 
Mathis Robert, Jackson John. 2002. Manajemen Sumber Daya Manusia. Jakarta : Salemba empat.

Mathis L. Robert dan Jackson H. John, 2001. Manajemen Sumberdaya Manusia, Jakarta : Buku kedua

Mulyadi. 2007. Sistem Perencanaan dan Pengendalian Manajemen. Jakarta: Salemba Empat.

Noor Juliansyah. 2013 “Buku Praktis Pengembangan SDM” Cetakan keenam.

Sudarmanto. 2009. Kinerja dan Pengembangan Kompetensi SDM,. Yogyakarta: Pustaka Pelajar.

Sunyoto Danang. 2013. Manajemen Sumber Daya Manusia, CAPS (Center Of. Academic Publishing Service), Yogyakarta. Edy Sutrisno. 2013. Manajemen

Robbins Stephen P. dan Judge Timothy A. 2008. Manajemen Sumberdaya Manusia. Perusahaan Cetakan ke-8, Bandung : Rosda. Perilaku Organisasi Edisi 10.

Simanjuntak, P.J.2011. Manajemen dan Evaluasi Kinerja. Lembaga Penerbit Univ. Indonesia, Jakarta.

Siagian, Sondang P. 2003. Teori dan Praktek Kepemimpinan. PT. Rineka Cipta. Jakarta.

Sopiah. 2008. Perilaku Organisasi, Yogyakarta : Andi

Sugiyono. 2014. Metode Penelitian Pendidikan Pendekatan Kuantitatif, Kualitatif, dan R\&D. Bandung: Alfabeta.

Tangkilisan, Hessel Nogi S, 2007, Manajemen Publik, Jakarta: Grasindo 